\title{
Synthesis and antimicrobial evaluation of some new quinazolin-4(3H)-one derivatives
}

\author{
Naglaa Fawzy a, Madeha Othman Ibrahim Ghobashy b and Ahmed Kamel El-Ziaty a,* \\ a Chemistry Department, Faculty of Science Ain Shams University, Abbassia, Cairo, 11566, Egypt \\ b Microbiology Department, Faculty of Science Ain Shams University, Abbassia, Cairo, 11566, Egypt \\ *Corresponding author at: Chemistry Department, Faculty of Science Ain Shams University, Abbassia, Cairo, 11566, Egypt. \\ Tel.: +2.0100.4943141; Fax: +2.24831836. E-mail address: ahm512@sci.asu.edu.eg (A.K. El-Ziaty).
}

\section{ARTICLE INFORMATION}

Received: 11 September 2012

Received in revised form: 20 September 2012

Accepted: 20 September 2012

Online: 31 December 2012

\section{KEYWORDS}

\section{Oxazolone}

Quinazolin-4-one

Triazinoquinazolin

Antimicrobial activity

Imidazoloquinazoline

Quinolinone-3-carboxylic acid

\section{Introduction}

The chemistry of heterocyclic compounds has been an interesting field of study for a long time [1-6]. The synthesis of novel quinazolin derivatives and investigation of their chemical and antimicrobial behavior has gained more importance in recent decades for biological, medicinal and agricultural reasons [5-9]. Quinazolinone nucleus has been gaining prominence due to the fact that its derivatives have been found to possess wide spectrum of pharmacological properties. Quinazolin-4(3H)-one derivatives are useful heterocycles, possessing potent pharmacological activities such as antibacterial, antifungal, analgesic, anti-inflammatory, anthelminthic, anticancer, anticonvulsant [10]. Quinazolin$4(3 \mathrm{H})$-ones having various heterocycles possesses wide range of pharmacological properties. Benzoxazine and quinazoline derivatives are important classes of heterocyclic compounds and are shown to have potent central nervous system (CNS) activities such as anticonvulsant and CNS depressant [11], antihistaminic activity [12], and other biological importance [13-15], so it is worthy to synthesis some newly qinazolin$4(3 H)$-one derivatives and tested their antimicrobial activities.

\section{Experimental}

\subsection{Instrumentation}

Melting points reported are uncorrected. IR spectra were recorded on Pye Unicam SP 1200 spectrophotometer using the $\mathrm{KBr}$ wafer technique. ${ }^{1} \mathrm{H}$ NMR spectra were determined on a Varian FT-200 and Bruker AC-200 MHz using TMS as internal standard. All chemical shifts $(\delta)$ are expressed in ppm. All NH or $\mathrm{OH}$ protons disappeared by deuterium exchange (addition of $\mathrm{D}_{2} \mathrm{O}$ ). Mass spectra were determined on MP model MS-5988 and Shimadzu single focusing mass spectrophotometer, (70 $\mathrm{eV})$.

\subsection{Synthesis}

\subsubsection{4-(Anthracen-9-ylmethyene)-2-phenyloxazol-5(4H)-} one (1)

A mixture of hippuric acid (1.79 g, $0.01 \mathrm{~mol})$, anthracen-9carbaldehyde $(2.06 \mathrm{~g}, 0.01 \mathrm{~mol})$ and freshly prepared fused sodium acetate $(2.46 \mathrm{~g}, 0.03 \mathrm{~mol})$ was wetted with $(5 \mathrm{~mL})$ freshly distilled acetic anhydride, and heated on hot plate for $10 \mathrm{~min}$, the reaction proceeded by forming a mass reddish brown paste. The reaction mixture was poured onto warm water, the solid formed was collected by filtration, dried and recrystallized from 1,4-dioxane to give compound 1 as orange crystals (Scheme 1). M.p: 240-241 ${ }^{\circ} \mathrm{C}$. Yield: $80 \%$. IR (KBr, v, cm $\left.{ }^{1}\right): 1792(\mathrm{C}=0), 1657(\mathrm{C}=\mathrm{N}) .{ }^{1} \mathrm{H}$ NMR $\left(200 \mathrm{MHz}, \mathrm{DMSO}-d_{6}, \delta\right.$, ppm): $8.78(\mathrm{~s}, 1 \mathrm{H}, \mathrm{C}=\mathrm{CH}), 8.30-7.49(\mathrm{~m}, 14 \mathrm{H}, \mathrm{Ar}-\mathrm{H}) . \mathrm{MS}(\mathrm{m} / \mathrm{z}$ (\%)): 349 ([M+.], 82), 321 (2), 216 (23), 189 (18), 105 (100). Anal. calcd. for $\mathrm{C}_{24} \mathrm{H}_{15} \mathrm{NO}_{2}$ : C, 82.52; $\mathrm{H}, 4.33$; N, 4.01. Found: $\mathrm{C}$, 82.47; H, 4.29; N, 3.98\%.

\subsubsection{2-(3-(Anthracen-9-yl)-2-benzamidoacrylamido) benzoic acid (2)}

A mixture of (1) (0.349 g, $0.001 \mathrm{~mol})$ and anthranilic acid $(0.137 \mathrm{~g}, 0.001 \mathrm{~mol})$ in $30 \mathrm{~mL}$ glacial acetic acid was heated under reflux for 6 hours, the solvent was concentrated and diluted by water. The solid product separated was filtered off, dried and recrystallized from benzene to give compound $\mathbf{2}$ as yellow crystals (Scheme 1). M.p: 221-222 ${ }^{\circ}$ C. Yield: 60\%. IR $\left(\mathrm{KBr}, v, \mathrm{~cm}^{-1}\right): 3320,3244(\mathrm{NH}, \mathrm{OH}), 1695,1677$ (C=0).

European Journal of Chemistry 


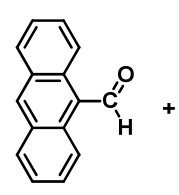<smiles>CNC(=O)c1ccccc1</smiles>

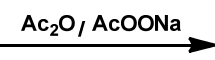<smiles></smiles><smiles>[CH]=C(C)NC(=O)Oc1ccccc1</smiles><smiles>[Z]c1nc2ccccc2c(=O)o1</smiles>

(3)

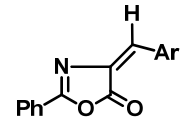

(1)
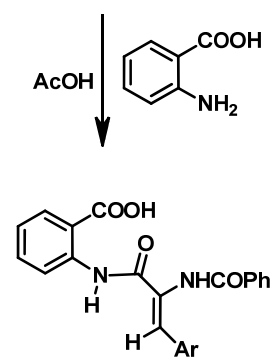

(2)

Scheme 1

${ }^{1} \mathrm{H}$ NMR (200 MHz, DMSO- $\left.d_{6}, \delta, \mathrm{ppm}\right): 12.37$ (s, $1 \mathrm{H}, \mathrm{COOH}$ ), 9.16 (s, 2H, NH), 8.29 (s, 1H, C=CH), 8.31-7.22 (m, 18H, Ar-H). MS $(\mathrm{m} / \mathrm{z},(\%)): 486\left(\left[\mathrm{M}^{+}\right], 4\right), 468(10), 363(10), 322$ (3), $146(5)$, 319 (9), 229 (100) 105 (44). Anal. calcd. for $\mathrm{C}_{31} \mathrm{H}_{22} \mathrm{~N}_{2} \mathrm{O}_{4}$ : C, 76.53; H, 4.56; N, 5.76. Found: C, 76.35; H, 4.54; N, 5.73\%.

\subsubsection{2-[1-Benzoylamino-2-(anthracene-9-yl)-1-vinyl] benzo[d][1,3]oxazin-4-one (3)}

A mixture of (2) (0.486 g, $0.001 \mathrm{~mol})$ and $25 \mathrm{~mL}$ freshly distilled acetic anhydride was heated for 2 hours, the excess acetic anhydride was evaporated under reduced pressure and. the solid formed was recrystallized by a mixture of benzene/ethanol to give compound $\mathbf{3}$ as yellow crystals (Scheme 1). M.p: 241-242 ${ }^{\circ} \mathrm{C}$. Yield: $50 \%$. IR $\left(\mathrm{KBr}, v, \mathrm{~cm}^{-1}\right)$ : 3291(NH) 1738, 1677 (C=0), 1610 (C=N). ${ }^{1} \mathrm{H}$ NMR (200 MHz, DMSO- $\left.d_{6}, \delta, \mathrm{ppm}\right): 9.92(\mathrm{~s}, 1 \mathrm{H}, \mathrm{NH}), 8.67(\mathrm{~s}, 1 \mathrm{H}, \mathrm{C}=\mathrm{CH}), 8.32-$ 7.32 (m, 18H, Ar-H). MS (m/z, (\%)): 468 (4), 348 (44), 347 (100), 319 (9). Anal. calcd. for $\mathrm{C}_{31} \mathrm{H}_{20} \mathrm{~N}_{2} \mathrm{O}_{3}$ : C, 79.49; $\mathrm{H}, 4.30 ; \mathrm{N}$, 5.78. Found: C, 79.29; H, 4.28; N, 5.68\%.

\subsubsection{3-Substituted quinazoline derivatives (4a-c)}

A mixture of $3(0.468 \mathrm{~g}, 0.001 \mathrm{~mol})$ and primary amine $(0.001 \mathrm{~mol})$ (Benzylamine, 4-chloroaniline and 4-methoxy aniline) in $20 \mathrm{~mL}$ ethanol was heated under reflux for 4 hours the solid which precipitated upon cooling was filtered and recrystallized from suitable solvent to give $\mathbf{4 a - c}$ (Scheme 2).

2-[1-Benzoylamino-2-(anthracene-9-yl)-1-vinyl]-3-benzylquinazolin-4-one (4a): Yellow crystals, recrystallized from 1,4dioxane. M.p: $211-212{ }^{\circ} \mathrm{C}$. Yield: 50\%. IR (KBr, v, cm-1): 3275 (NH), $1678(\mathrm{C}=0), 1625(\mathrm{C}=\mathrm{N}) .{ }^{1} \mathrm{H}$ NMR $\left(200 \mathrm{MHz}, \mathrm{DMSO}-d_{6}, \delta\right.$, ppm): $9.32(\mathrm{~s}, 1 \mathrm{H}, \mathrm{NH}), 8.21(\mathrm{~s}, 1 \mathrm{H}, \mathrm{C}=\mathrm{CH}), 8.23-7.11(\mathrm{~m}, 23 \mathrm{H}$, Ar-H), 5.42 (s, 2H, benzylic-H). Anal. calcd. for $\mathrm{C}_{38} \mathrm{H}_{27} \mathrm{~N}_{3} \mathrm{O}_{2}$ : C, 81.85; H, 4.88; N, 7.54. Found: C, 81.91; H, 4.87; N, 7.53\%.

2-[1-Benzoylamino-2-(anthracene-9-yl)-1-vinyl]-3-(4-chloro phenyl) quinazolin-4-one (4b): Brown crystals, recrystallized from a mixture of ethanol and 1,4-dioxane. M.p.: 232-233 ${ }^{\circ} \mathrm{C}$. Yield: 45\%. IR (KBr, v, cm-1): $3247(\mathrm{NH}), 1676(\mathrm{C}=0), 1631$ $(\mathrm{C}=\mathrm{N})$. Anal. calcd. for $\mathrm{C}_{37} \mathrm{H}_{24} \mathrm{ClN}_{3} \mathrm{O}_{2}$ : C, 77.28; $\mathrm{H}, 4.21 ; \mathrm{N}, 7.31$. Found: C, 77.19; H, 4.19; N, 7.29\%.

2-[1-Benzoylamino-2-(anthracene-9-yl)-1-vinyl]-3-(4-methoxyphenyl) quinazolin-4-one (4c): Pale yellow crystals, recrystallized from a mixture of ethanol and 1,4-dioxane. M.p.: 222-223 ${ }^{\circ} \mathrm{C}$. Yield: 50\%. IR (KBr, v, cm$\left.{ }^{-1}\right): 3210(\mathrm{NH}), 1677$ $(\mathrm{C}=0), 1620(\mathrm{C}=\mathrm{N})$. MS (m/z, (\%)): 573 (40), 466 (41), 453
(50), 145 (100). Anal. calcd. for $\mathrm{C}_{38} \mathrm{H}_{27} \mathrm{~N}_{3} \mathrm{O}_{3}$ : C, 79.56; $\mathrm{H}, 4.74 ; \mathrm{N}$, 7.33. Found: C, 79.49; H, 4.68; N, 7.31\%.

\subsection{5. $N$-Substituted benzamide derivatives $(5 \mathrm{a}, \mathrm{b})$}

A mixture of $3(0.468 \mathrm{~g}, 0.001 \mathrm{~mol})$ and secondary amine ( $0.001 \mathrm{~mol}$ ) (viz piperidine and morpholine) in $20 \mathrm{~mL}$ ethanol was heated under reflux for 4 hours the solid which separated upon cooling was filtered and recrystallized from suitable solvent to give compound $\mathbf{5 a , b}$ (Scheme 2).

$\mathrm{N}$-(3-(Anthracen-9-yl)-1-oxo-1(2-(piperidine1-carbonyl) phenylamino)prop2-en-2-yl) benzamide (5a): Brown crystals, recrystallized 1,4-dioxane. M.p.: 260-261 ${ }^{\circ} \mathrm{C}$. Yield: $40 \%$. IR $\left(\mathrm{KBr}, v, \mathrm{~cm}^{-1}\right): 3210(\mathrm{NH}), 1677(\mathrm{C}=0), 1620(\mathrm{C}=\mathrm{N}) . \mathrm{MS}(\mathrm{m} / \mathrm{z}$, (\%)): 553 (43), 468 (14), 363 (50), 347 (100). Anal. calcd. for $\mathrm{C}_{36} \mathrm{H}_{31} \mathrm{~N}_{3} \mathrm{O}_{3}$ : C, 78.10; H, 5.64; N, 7.60. Found: C, 78.08; H, 5.60; N, $7.58 \%$.

N-(3-(Anthracen-9-yl)-1-(2-(morpholine-4-carbonyl) phenyl amino) 1-oxoprop2-en-2-yl)benzamide (5b): Pale yellow crystals recrystallized from 1,4-dioxane. M.p.: 232-233 ${ }^{\circ} \mathrm{C}$. Yield: 45\%. IR (KBr, v, cm$\left.{ }^{-1}\right)$ : $3210(\mathrm{NH}), 1677(\mathrm{C}=0), 1620$ $(\mathrm{C}=\mathrm{N})$. Anal. calcd. for $\mathrm{C}_{35} \mathrm{H}_{29} \mathrm{~N}_{3} \mathrm{O}_{4}$ : C, 75.63; $\mathrm{H}, 5.26$; N, 7.56. Found: $\mathrm{C}, 75.59 ; \mathrm{H}, 5.18 ; \mathrm{N}, 7.51 \%$.

\subsubsection{2-(2-(Anthracen-9-yl)-1-benzamidovinyl)-4-oxo-3,4- dihydroquinoline-3carboxylicacid (6)}

A mixture of compound $3(0.468 \mathrm{~g}, 0.001 \mathrm{~mol})$ and active methylene compounds $(0.001 \mathrm{~mol})$ (Malononitrile and etyl cyanoacetate) in $20 \mathrm{~mL}$ dry pyridine was heated under reflux for 4 hours the solid which separated upon cooling was filtered and recrystallized from a mixture of ethanol and 1,4-dioxane to give compound $\mathbf{6}$ as pale brown crystals (Scheme 2). M.p.: 218$219{ }^{\circ} \mathrm{C}$. Yield: $55 \%$. IR (KBr, v, cm-1): 3380, $3145(\mathrm{NH}, \mathrm{OH})$, 1699, $1670(\mathrm{C}=0) .{ }^{1} \mathrm{H}$ NMR $\left(200 \mathrm{MHz}, \mathrm{DMSO}-d_{6}, \delta, \mathrm{ppm}\right): 12.48$ (s, 1H, COOH), $8.83(\mathrm{~s}, \mathrm{H}, \mathrm{NH}), 8.60(\mathrm{~s}, 1 \mathrm{H}, \mathrm{C}=\mathrm{CH}), 8.24-7.22(\mathrm{~m}$, $18 \mathrm{H}, \mathrm{Ar}-\mathrm{H}), 5.40(\mathrm{~s}, 1 \mathrm{H}, \mathrm{CH})$. Anal. calcd. for $\mathrm{C}_{33} \mathrm{H}_{22} \mathrm{~N}_{2} \mathrm{O}_{4}$ : C, 77.64; H, 4.34; N, 5.49. Found: C, 77.62; H, 4.29; N, 5.43\%.

\subsubsection{4-(Anthracen-9-ylmethylene)-2-phenyl-1H-[1,2,4]} triazino[6,1-b]quinazolino-10(4H)-one (7)

A mixture of compound 3 (0.468 g, $0.001 \mathrm{~mol})$ and hydrazine hydrate $(0.05 \mathrm{~mL}, 0.001 \mathrm{~mol})$ was heated under reflux for an hour the solid which separated upon cooling was filtered and recrystallized from ethanol/dioxane to give compound 7 as brown crystals . M.p.: $244-246^{\circ} \mathrm{C}$. Yield: $65 \%$. 


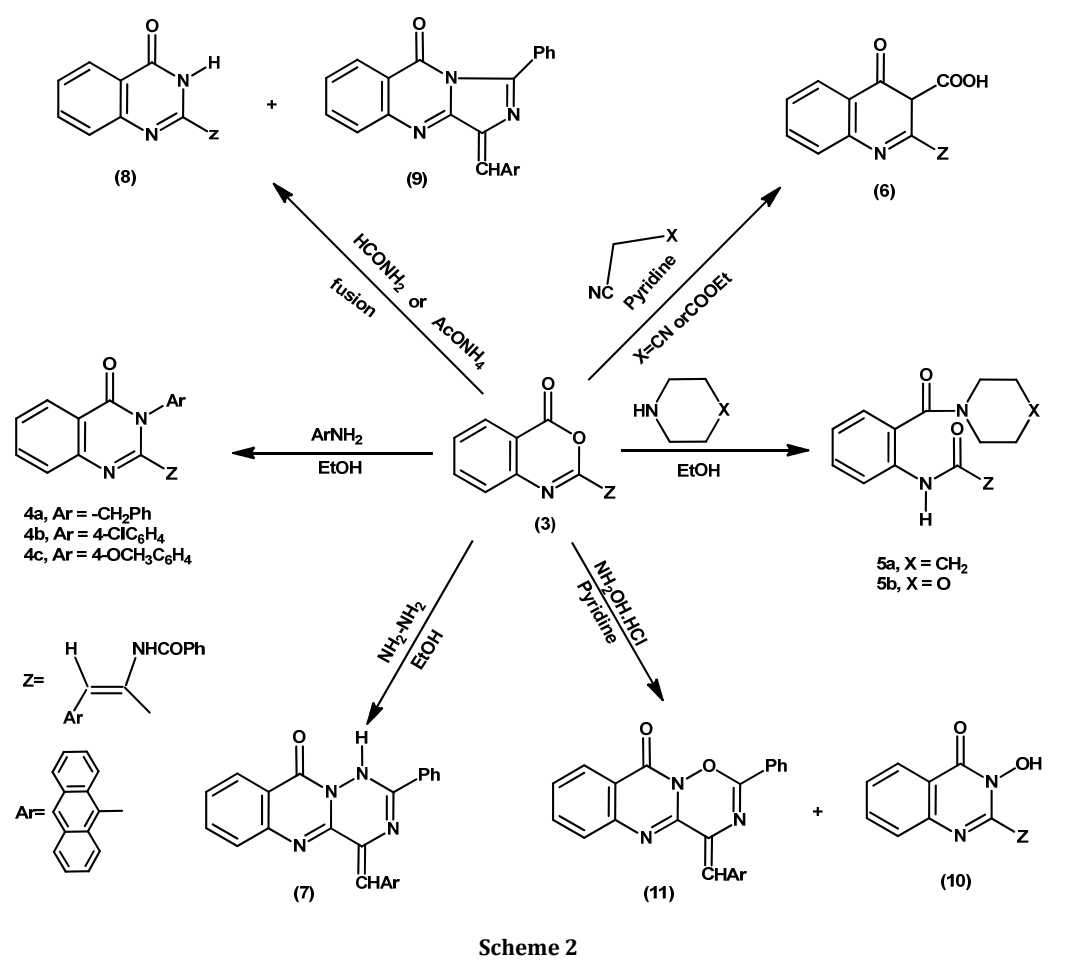

IR (KBr, v, cm $\left.{ }^{-1}\right)$ : $3145(\mathrm{NH}), 1690(\mathrm{C}=0) .{ }^{1} \mathrm{H}$ NMR $(200 \mathrm{MHz}$, DMSO- $\left.d_{6}, \delta, \mathrm{ppm}\right): 8.83(\mathrm{~s}, \mathrm{H}, \mathrm{NH}), 8.60(\mathrm{~s}, 1 \mathrm{H}, \mathrm{C}=\mathrm{CH}), 8.24-7.22$ (m, 18H, Ar-H). Anal. calcd. for $\mathrm{C}_{33} \mathrm{H}_{20} \mathrm{~N}_{4} \mathrm{O}: \mathrm{C}, 80.51 ; \mathrm{H}, 4.34 ; \mathrm{N}$, 12.06. Found: C, 79.98; H, 4.30; N, 11.98\%.

\subsubsection{2-[1-Benzoylamino-2-(anthracene-9-yl)-1-vinyl] quinazoline-4-one (8) and 3-(anthracen-9-ylmethylene)-1- phenylimidazo[5,1-b]quinazolin-9(3H)-one (9)}

A mixture of compound $3(0.468 \mathrm{~g}, 0.001 \mathrm{~mol})$, ammonium acetate $(0.077 \mathrm{~g}, 0.001 \mathrm{~mol})$ and $10 \mathrm{~mL}$ formamid was fused at $240-250{ }^{\circ} \mathrm{C}$ for an hour, then washed with hot water and the crude product was separated by fractional crystallization to give compound $\mathbf{8}$ and $\mathbf{9}$ (Scheme 2).

2-[1-Benzoylamino-2-(anthracene-9-yl)-1-vinyl] quinazoline4-one (8): Brown crystals, recrystallized from benzene. M.p.: 231-232 ${ }^{\circ}$ C. Yield: $40 \%$. IR (KBr, $\left.v, \mathrm{~cm}^{-1}\right): 3145,3380(\mathrm{NH}, \mathrm{OH})$, 1699, $1670(\mathrm{C}=0)$. MS ( $\mathrm{m} / \mathrm{z},(\%)): 468$ (39), $440(6), 424(50)$, 378 (50), 105 (34), 75 (100). Anal. calcd. for $\mathrm{C}_{31} \mathrm{H}_{21} \mathrm{~N}_{3} \mathrm{O}_{2}$ : C, 79.64; H, 4.53; N, 8.99. Found: C, 79.61; H, 4.49; N, 8.91\%.

3-(Anthracen-9-ylmethylene)-1-phenylimidazo[5,1-

b]quinazolin-9(3H)-one (9): Yellow crystals, recrystallized from a mixture of ethanol and 1,4-dioxane. M.p.: 211-212 ${ }^{\circ} \mathrm{C}$. Yield: 40\%. IR (KBr, v, cm-1 $): 1680(\mathrm{C}=0), 1623(\mathrm{C}=\mathrm{N}) .{ }^{1} \mathrm{H}$ NMR $(200$ MHz, DMSO- $\left.d_{6}, \delta, \mathrm{ppm}\right): 8.60(\mathrm{~s}, 1 \mathrm{H}, \mathrm{C}=\mathrm{CH}), 8.24-7.22(\mathrm{~m}, 18 \mathrm{H}$, Ar-H). Anal. calcd. for $\mathrm{C}_{31} \mathrm{H}_{19} \mathrm{~N}_{3} \mathrm{O}$ : C, 82.83; $\mathrm{H}, 4.26$; N, 9.35 . Found: $\mathrm{C}, 82.75 ; \mathrm{H}, 4.21 ; \mathrm{N}, 9.28 \%$.

\subsubsection{2-[1-Benzoylamino-2-(anthracene-9-yl)-1-vinyl]-3-} hydroxy quinazoline-4-one (10) and 4-(anthracen-9-yl methylen)-2-phenyl-[1,2,5]oxadiazino[3,2-b]quinazolin-10(4H)-one (11)

A mixture of compound 3 (0.468 g, $0.001 \mathrm{~mol})$ and hydroxyl amine hydrochloride $(0.067 \mathrm{~g}, 0.001 \mathrm{~mol})$ in $10 \mathrm{~mL}$ pyridine was heated under reflux for 8 hours, the reaction mixture was poured on ice cold hydrochloric acid, the solid which separated was filtered, dried and separated by fractional crystallization (Scheme 2).
2-[1-Benzoylamino-2-(anthracene-9-yl)-1-vinyl]-3-hydroxy quinazoline-4-one (10): Yellow crystals, recrystallized from of ethanol. M.p.: $214-215{ }^{\circ} \mathrm{C}$. Yield: $45 \%$. IR (KBr, $\left.v, \mathrm{~cm}^{-1}\right): 3383$ $(\mathrm{OH}), 1686(\mathrm{C}=0), 1622(\mathrm{C}=\mathrm{N})$. MS ( $\mathrm{m} / \mathrm{z},(\%)): 483(20), 466$ (7), 455 (8), 105 (20), 75 (100). Anal. calcd. for $\mathrm{C}_{31} \mathrm{H}_{21} \mathrm{~N}_{3} \mathrm{O}_{3}$ : C, 77.00; H, 4.38; N, 8.69. Found: C, 76.82; H, 4.29; N, 8.64\%.

4-(Anthracen-9-ylmethylen)-2-phenyl-[1,2,5]oxadiazino[3,2b]quinazolin-10-(4H)-one (11): Brown crystals, recrystallized from 1,4-dioxane. M.p.: $202-204{ }^{\circ} \mathrm{C}$. Yield: $40 \%$. IR (KBr, $v, \mathrm{~cm}$ 1): $1677(\mathrm{C}=0), 1610(\mathrm{C}=\mathrm{N}) .{ }^{1} \mathrm{H}$ NMR $\left(200 \mathrm{MHz}, \mathrm{DMSO}-d_{6}, \delta\right.$, ppm): 8.32 (s, $1 \mathrm{H}, \mathrm{C}=\mathrm{CH}), 8.24-7.22(\mathrm{~m}, 18 \mathrm{H}, \mathrm{Ar}-\mathrm{H})$. Anal. calcd. for $\mathrm{C}_{31} \mathrm{H}_{1}{ }_{19} \mathrm{~N}_{3} \mathrm{O}_{2}$ : C, 79.98; $\mathrm{H}, 4.11 ; \mathrm{N}, 9.03$. Found: $\mathrm{C}, 79.91 ; \mathrm{H}$, $4.09 ; \mathrm{N}, 8.98 \%$.

\subsection{Antimicrobial assay}

\subsubsection{Test organism}

Microorganisms were obtained from our culture collections of Department of Microbiology, Faculty of Science Ain Shams University. Five strains of Gram-negative bacteria (Escherichia coli, Pseudomonas aeruginosa, Klebsiella pneumoniae, Proteus mirabilis and Acinetobacter baumannii) and three strains of Gram-positive bacteria (Staphylococcus aureus, Streptococcus mutans and Bacillus subtilis), and one fungus strain Candida albicans were used. The cultures of bacteria were maintained in their appropriate agar slants at $4{ }^{\circ} \mathrm{C}$ throughout the study and used as stock cultures.

\subsubsection{Materials}

Mueller-Hinton agar and Mueller-Hinton broth medium were purchased from Diffco Company, dimethylsulfoxide and Tween 80 were supplemented by Chemistry Department, Faculty of Science, Ain Shams University. Gentamycin antibiotic were purchased from Pfizer Company. Fluconazole antibiotic were purchased from Pfizer Company. 


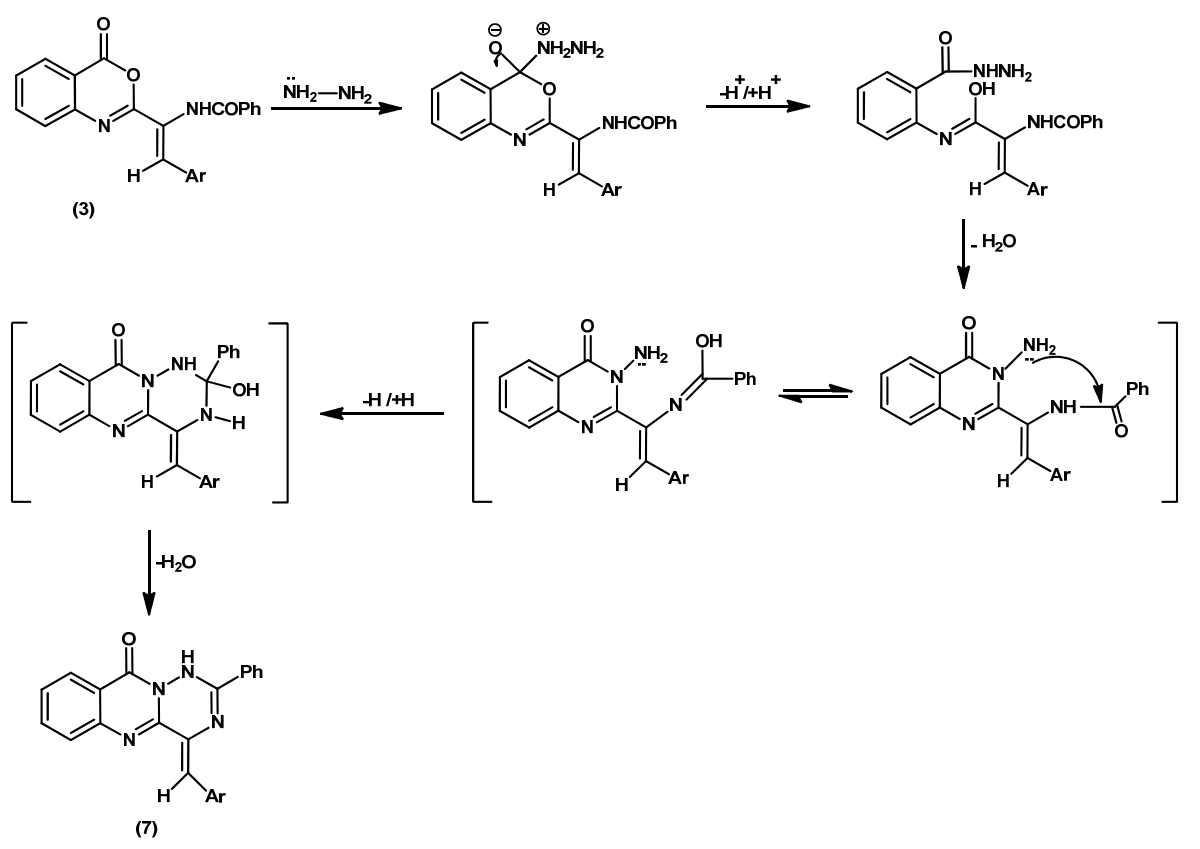

Scheme 3

\subsubsection{Evaluation of antibacterial activity}

The newly synthesized quinazolin derivatives were evaluated for their in vitro antimicrobial activity against five strains of Gram-negative bacteria, (Escherichia coli, Pseudomonas aeruginosa, Klebsiella pneumoniae, Proteus mirabilis and Acinetobacter baumannii) and three strains of Gram-positive bacteria, (Staphylococcus aureus, Streptococcus mutans and Bacillus subtilis), and one fungus strain Candida albicans were used.

Screening of synthesized compounds for antimicrobial activity was done by the diffusion method, which is normally used as a preliminary check and to select between efficient chemical compounds. Gentamycin was used as standard drug for bacteria, and Fluconazole as standard drug for fungi. Under aseptic conditions, it was performed using an $18 \mathrm{~h}$ culture at 37 ${ }^{\circ} \mathrm{C}$ in $10 \mathrm{~mL}$ of Mueller Hinton Broth. 20 Milliliters of MuellerHinton agar poured into sterile petri dishes and allowed for solidification. Wells was made in agar plates using sterile cork of $8 \mathrm{~mm}$ diameter. The cultures were adjusted to approximately $10^{6} \mathrm{CFU} / \mathrm{mL}$ with sterile saline solution. Five hundred microliters of the suspensions were spread over the plates containing Mueller-Hinton agar using a sterile cotton swab in order to get a uniform microbial growth on both control and test plates.

The different chemical compounds were dissolved in $10 \%$ aqueous dimethylsulfoxide (DMSO) with Tween $80(0.5 \%, v: v$ for easy diffusion) and sterilized by filtration through a $0.22 \mu \mathrm{m}$ membrane filter. $20 \mu \mathrm{L}(0.02 \mathrm{mg} / \mathrm{mL})$ of each solution of chemical compounds were added separately to the wells in the petri dishes. The plates were left for $120 \mathrm{~min}$ at $4{ }^{\circ} \mathrm{C}$ to allow the diffusion of compounds, and then they were incubated at 37

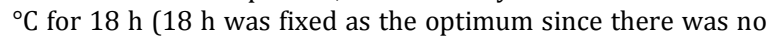
change in the inhibition up to $24 \mathrm{~h}$ ) After the incubation period, the zone of inhibition was measured with a caliper, and compared with the reading of inhibition zone produced by using $(20 \mu \mathrm{g} / \mathrm{mL})$ of gentamycin, and fluconazole antibiotic solution as positive control. Studies were performed in twice, and mean value was calculated. The means were analyzed by the statistics methods.

\section{Results and discussion}

\subsection{Chemistry}

In the present work, new 4-(9'-anthracylmethlene)-2phenyloxazol-5-one (1) has been synthesized via the reaction of hippuric acid with 9-anthraldehyde under PerkinErlenmeyer reaction conditions, and underwent ring opening by reaction with anthranilic acid as a fission of the 1,5-bond of oxazolin-5-one by the amino moiety to give 2-(3-(anthracen10-yl)-2-benzamidoacrylamido)benzoic acid (2), which underwent ring closure by heating with acetic anhydride to give 2-[1-benzoylamino-2-(anthracene-10-yl)-1-vinyl]-4(H) benzo[d][1,3]oxazin-4-one (3) (Scheme 1).

Benzoxazinone derivative, 3, was subjected to react with primary aromatic amines such as 4-chloroaniline, 4-methoxyaniline, and benzylamine, as nitrogen nucleophiles aiming to synthesis of some newly quinazolin-4 $(3 H)$-one derivatives, 4ac) which expected to have antimicrobial activity.

It is worth mentioning to study the reactivity of benzoxazinone, 3 , towards secondary amines, such pipridine and morpholine as nitrogen nucleophiles. Ring opening of compound $\mathbf{3}$ with secondary amines gave the corresponding amid derivatives $\mathbf{5 a}, \mathbf{b}$.

In continuation of our interest in synthesis and studying the reaction behavior of benzoxazinones and quinazolinones [16-20] we reported herein the behaviour of the benzoxazinone derivative, 3 , with some active methylene compounds as carbone nucleophile, so the benzoxazinone derivative, 3, was reacted with ethyl cyanoacetate and/or malononitrile in pyridine to give 2-(2-(anthracen-9-yl)-1benzamidovinyl)-4-oxo-3,4-dihydro-quinoline-3-carboxylic acid, 6 , via ring opening and ring closure of the benoxazinone derivative, 3, followed by hydrolysis of the cyano or the ethylester group to the carboxylic group. The structure of compound 6 was confirmed from the ${ }^{1} \mathrm{H}$ NMR spectrum showing the $\delta$ value at $12.48 \mathrm{ppm}$ for singlet, one proton, corresponding to the carboxylic hydrogen and disappeared by $\mathrm{D}_{2} \mathrm{O}$, hydrazinolysis of compound $\mathbf{3}$ in boiling ethanol afforded the triazinoquinqzolinone derivative, $\mathbf{7}$, according to the following mechanism (Scheme 3). 
Table 1. Antimicrobial activity (as inhibition zone in mm diameter) of synthesized compounds *

\begin{tabular}{|c|c|c|c|c|c|c|c|c|c|c|c|c|c|}
\hline \multirow[t]{2}{*}{ Microorganism } & \multicolumn{11}{|c|}{ Antimicrobial activity / Sample no } & \multirow[t]{2}{*}{ Gentamycin } & \multirow[t]{2}{*}{ Fluconazole } \\
\hline & 1 & 2 & 3 & $4 a$ & $5 \mathbf{a}$ & 6 & 7 & 8 & 9 & 10 & 11 & & \\
\hline Klebsiella pneuтоniae & - & - & - & - & - & 17 & 14 & 17 & 16 & - & 16 & 31 & - \\
\hline Pseudomonas aeruginosa & 18 & 16 & 21 & 20 & - & 21 & 25 & 21 & 20 & 22 & 25 & 32 & - \\
\hline Escherichia coli & - & - & - & - & - & - & - & - & - & - & - & 32 & - \\
\hline Proteus mirabilis & - & - & - & - & - & - & 13 & - & - & - & - & 22 & - \\
\hline Acinetobacter baumannii & 17 & 16 & 12 & 12 & - & 16 & 12 & 12 & 13 & - & - & 34 & - \\
\hline Bacillus subtilis & - & - & - & - & - & - & - & - & - & 20 & 17 & 26 & - \\
\hline Streptococcus mutans & - & - & 13 & 12 & - & 13 & 13 & 16 & - & 25 & - & 35 & - \\
\hline Staphylococcus aureus & - & - & - & - & - & - & - & - & - & - & - & 26 & - \\
\hline Candida albicans & 15 & - & - & 18 & - & 17 & 14 & 17 & 16 & 17 & 15 & - & 27 \\
\hline
\end{tabular}

* Standard antibacterial antibody is Gentamycin $(20 \mu \mathrm{g} / \mathrm{mL})$, standard antifungal antibody is Fluconazole (20 $\mu \mathrm{g} / \mathrm{mL})$. All pathogenic microorganisms are isolated and identificated by the staff members of Microbiology Department, Faculty of Science, Ain Shams University.

The structure of compound $\mathbf{7}$ was substantiated from studying its IR spectrum which lacks $v \mathrm{NH}_{2}$ bands, and ${ }^{1} \mathrm{H}$ NMR spectrum which showed the signal characteristic of one $\mathrm{NH}$ proton. On the other hand, fusion of compound $\mathbf{3}$ with ammonium acetate and/or formamid gave a mixture of quinazoline derivative, $\mathbf{8}$, and imidazolo[5,1-b]quinazolin$9(3 H)$-one, 9. The mixture was separated by fractional crystallization (see experimental part).

Ring opening of compound $\mathbf{3}$ with hydroxylamine hydrochloride in the presence of pyridine as a base gave a mixture of quinqzolinone derivative, 10, and $[1,2,5]$ oxadiazino [3,2-b]quinazolin-10(4H)-one, 11 (Scheme 2).

The structures of the synthesized compounds were assigned from studying their spectral data, such as IR, ${ }^{1} \mathrm{H}$ NMR, Mass spectra, as well as elemental analysis $[1,2,8]$.

\subsection{Antimicrobial assay}

Antibiotic resistance is a growing problem, some of this is due to the overuse of antibiotics in human, but some of it is probably due to the use of antibiotics as growth promoters in food of animals. So, there is a growing demand for new antibiotics.

The synthesized new quinazolin derivatives were evaluated for their in vitro antimicrobial activity against five strains of Gram-negative bacteria (Escherichia coli, Pseudomonas aeruginosa, Klebsiella pneumoniae, Proteus mirabilis and Acinetobacter baumannii) and three strains of Gram-positive bacteria (Staphylococcus aureus, Streptococcus mutans and Bacillus subtilis), and one fungus strain Candida albicans were used.

Based on the results of zone of inhibition, data in Table 1 revealed that $20 \mu \mathrm{g} / \mathrm{mL}$ was the most potent quinazolin derivative against bacterial strains, in addition, it was as potent as gentamycin antibiotic compounds $20 \mu \mathrm{g} / \mathrm{mL}$ were effective in inhibiting the growth of the tested bacterial strains. Compounds 3, 4a, 6-11, exhibited different antibacterial and antifungal capabilities against Klebsiella pneumoniae, Pseudomonas aeruginosa, Acinetobacter baumannii, Streptococcus mutans and Candida albicans. However Escherichia coli and Staphylococcus aureus showed a complete resistant against the tested 11 novel quinazolin derivatives. The anti-bacterial activity of compounds $4 \mathbf{a}$ and 6-11 were greater than the rest compounds on Klebsiella pneumoniae, Pseudomonas aeruginosa, Acinetobacter baumannii, Streptococcus mutans and Candida albicans. In regard with the inhibitory effect of gentamycin and fluconazole antibiotics, the tested quinazolin derivatives showed high inhibitory activity as noticed by compounds $7, \mathbf{1 0}$ and $\mathbf{1 1}$ while the rest compounds 1, 2, 3, 4a, 6, 8 and 9 had mild activity. All the tested quinazolin derivatives exhibited no effect against Escherichia coli and Staphylococcus aureus and only very week effect against Bacillus subtilis and Proteus mirabilis. The remaining compounds possessed moderate activities against both fungi as compared to standard.

\section{Conclusion}

The new compounds were successfully synthesized using well known methods. Most compounds were found to be very active towards Gram-positive bacteria, few other compounds showed higher activity towards Gram-negative bacteria whereas some compound exhibited very good activity against fungi among the series. These findings give some idea about further research on this molecule with hope to get biologically active molecule.

\section{Acknowledgement}

The spectral data were carried out in the Microanalytical Center, Cairo University, Egypt.

\section{References}

[1]. Murti, Y.; Singh, A. K.; Pathak, D. Indian J. Pharm. Sci. 2011, 73(3), 333337.

[2]. Akhaja, T. N.; Raval, J. P. Eur. J. Med. Chem. 2011, 46(11), 5573-5579.

[3]. Chavan, V. P.; Sonawane, S. A.; Shingare, M. S.; Karale, B. K. Chem. Heterocyclic. Comp. 2006, 42, 625-630.

[4]. Patel, N. B.; Patel, J. C. Sci. Pharm. 2010, 78, 171-193.

[5]. Zheng, X.; Li, Z.; Wang, Y.; Chen, W.; Huang, Q.; Liu, C.; Song, G. J. Fluorine. Chem. 2003, 123, 163-169.

[6]. Thoraya, A. F.; Mastoura, M. E.; Mosselhi A. M. Molecules 2012, 17, 8483-8493.

[7]. Hollaa, B. S.; Gonsalves, R.; Shenoy, S. Eur. J. Med. Chem. 2000, 35, $267-$ 271.

[8]. Liu, F.; Luo, X.; Song, B.; Bhadury, P. S.; Yang, S.; Jin, L.; Xue, W.; Hu, D. Bioorg. Med. Chem. 2008, 16, 3632-3640.

[9]. Narayana, B.; Raj, K. K. V.; Ashalatha, B. V.; Kumari, N. S. Arch. Pharm 2005, 338, 373-377.

[10]. Patel, N. B.; Patel, J. C. Sci. Pharm. 2010, 78, 171-193.

[11]. Kumar, P.; Shrivastave, B.; Pandeya, S. N.; Stables, J. P. Eur. J. Med. Chem. 2001, 46, 1006-1018.

[12]. Alagarsamy, V.; Shankar, D.; Murugesan, S. Biomed. Pharm. 2008, 62, 173-179.

[13]. Belluci, C.; Gualtieri, F.; Chiarine, A. Eur. J. Med. Chem. 1987, 22, 473477.

[14]. Kranta, A.; Spencer, R. W.; Tam, T. F.; Liak, T. J.; Copp, L. J.; Thoman, E. M.; Rafferty, S. P. J. Med. Chem. 1990, 33, 464-479.

[15]. Panneerselvam, P.; Rather, B. A.; Reddy, D. R. S.; Kumar, N. R. Eur. J. Med. Chem. 2008, 43, 1-6.

[16]. Mahmoud, R. M.; El-Ziaty, A. K.; Shiba, S. A.; Ismail, M. F. Eur. J. Chem 2011, 2(3), 347-355.

[17]. El-Ziaty, A. K.; Shiba, S. A. Synthetic Commun. 2007, 37(22), 40434057.

[18]. Shiba, S. A.; El-Ziaty, A. K.; El-Aaser, N. K.; Al-Saman, H. A. J. Chem. Res. 2008, 9, 500-506.

[19]. Shiba, S. A.; El-Ziaty, A. K.; El-Aaser, N. K.; Al-Saman, H. A. Phosphorus Sulfur 2010, 185(8), 1645-1657.

[20]. El-Ziaty, A. K.; Abdalh, A. A.; Hamed, A. A.; Shiba, S. A.; Abdullah, A. Eur J. Chem. 2012, 3(1), 65-70. 